\title{
Short communication: Production of cottage cheese fortified with vitamin D
}

\author{
Benoît Crevier, ${ }^{*} \dagger$ Gaétan Bélanger, ${ }^{*}$ Jean-Christophe Vuillemard, $†$ and Daniel St-Gelais ${ }^{*}{ }^{1}$ \\ *St-Hyacinthe Research and Development Centre, Agriculture and Agri-Food Canada, 3600 Casavant Boulevard West, St-Hyacinthe, QC, \\ J2S 8E2, Canada \\ †Institut sur la Nutrition et les Aliments Fonctionnels, Centre de Recherche en Sciences et Technologie du Lait, Université Laval, Quebec City, \\ QC, G1V 0A6, Canada
}

\begin{abstract}
The availability of alternative food products fortified with vitamin $\mathrm{D}$ could help decrease the percentage of the population with vitamin $\mathrm{D}$ deficiency. The objective of this study was to fortify cheese with vitamin D. Cottage cheese was selected because its manufacture allows for the addition of vitamin $\mathrm{D}$ after the draining step without any loss of the vitamin in whey. Cream containing vitamin D (145 IU/g of cream) was mixed with the fresh cheese curds, resulting in a final concentration of $51 \mathrm{IU} / \mathrm{g}$ of cheese. Unfortified cottage cheese was used as a control. As expected, the cottage cheese was fortified without any loss of vitamin D in the cheese whey. The vitamin D added to cream was not affected by homogenization or pasteurization treatments. In cottage cheese, the vitamin $\mathrm{D}$ concentration remained stable during 3 weeks of storage at $4^{\circ} \mathrm{C}$. Compared with the control cheese, the cheese fortified with vitamin D showed no effects of fortification on cheese characteristics or sensory properties. Cottage cheese could be a new source of vitamin D or an alternative to fortified drinking milk.
\end{abstract}

Key words: cottage cheese, vitamin D, storage, stability

\section{Short Communication}

Vitamin D improves the intestinal absorption of calcium and phosphorus and reduces the risk of bonerelated diseases, autoimmune diseases, and cancers (Institute of Medicine, 2011). In Canada, drinking milk is fortified to provide vitamin D and help the population meet the Recommended Dietary Allowance (RDA). However, Whiting et al. (2011) reported that only $65 \%$ of Canadians had a dietary intake at or above $50 \mathrm{nmol} / \mathrm{L}$ and that one-quarter did not meet the RDA (a proportion that rose to more than one-

Received November 14, 2016.

Accepted March 24, 2017.

${ }^{1}$ Corresponding author: daniel.st-gelais@agr.gc.ca third in the winter). In that study, 5.4, 12.7, and $25.7 \%$ of Canadian participants had plasma levels below the cutoffs of 30,40 , and $50 \mathrm{nmol} / \mathrm{L}$, respectively. These results suggest that current milk fortification alone is insufficient to maintain vitamin D plasma concentrations of $50 \mathrm{nmol} / \mathrm{L}$, especially in the winter. Moreover, vitamin $\mathrm{D}$ deficiency could be considered a worldwide problem (Holick and Chen, 2008; Lips, 2010), and low serum vitamin $\mathrm{D}$ concentrations increase the risk of bone mineral loss (rickets in children or osteomalacia in adults), osteoporosis, and fractures (Langlois et al., 2010). Previous studies have reported on the vitamin D fortification of Cheddar cheese (Wagner et al., 2008; Tippetts et al., 2012; Boivin-Piché et al., 2016). The results showed that the vitamin $\mathrm{D}$ was not affected by milk pasteurization (Wagner et al., 2008; Kaushik et al., 2014; Boivin-Piché et al., 2016) and remained relatively stable during Cheddar cheese manufacture (Kazmi et al., 2007; Wagner et al., 2008; Boivin-Piché et al., 2016) and ripening (Banville et al., 2000; Wagner et al., 2008; Boivin-Piché et al., 2016). However, a large proportion of the added vitamin $\mathrm{D}$ is lost during the wheying-off step of cheese manufacturing (Banville et al., 2000; Kazmi et al., 2007; Wagner et al., 2008), contaminating the whey and making it difficult to use for other purposes. Boivin-Piché et al. (2016) reported that concentration of the milk by ultrafiltration before Cheddar cheese production reduced the vitamin D loss in whey with relatively low efficiency. Cottage cheese could be a better option for vitamin D fortification than Cheddar cheese. The distinctive feature of cottage cheese manufacture is the mixing of skimmed curd grains with salted and standardized cream (Araújo et al., 2012). Dispersing the vitamin D in the cream could make it possible to obtain fortified cottage cheese without vitamin loss in the whey. The objective of this study was to fortify cottage cheese with vitamin D dispersed in the cream and evaluate the characteristics of the resulting cheeses and the stability of the vitamin D.

Whole milk (500 L) obtained from Laiterie Chalifoux Inc. (Sorel-Tracy, QC, Canada) was skimmed in a separator (type 62181 m-60/1954; Alfa-Laval, Uppsala, 
Sweden). The skim milk (0.06\% milk fat, $3.35 \%$ total proteins, $9.10 \%$ total solids) was stored at $4^{\circ} \mathrm{C}$ until use. Cream (37.93\% milk fat, $1.77 \%$ total proteins, $43.04 \%$ total solids) was standardized to $14 \%$ milk fat with skim milk. After standardization, the cream composition was determined $(13.9 \%$ milk fat, $2.78 \%$ total proteins, $21.09 \%$ total solids). Then, $0.05 \%$ (wt/vol) xanthan gum and guar gum (TIC Gums, Belcamp, MD) were added at a ratio of $60: 40$, respectively. One portion of the cream was fortified with emulsified vitamin D (Vitamin D Premix; Kingsway Chocolate, Mississauga, ON, Canada), and the other was left unfortified as a control. Both creams were homogenized in 2 stages (13.8 and $3.45 \mathrm{MPa}$; Rannie, Charlotte, NC) and heat-treated at $85^{\circ} \mathrm{C}$ for $18 \mathrm{~s}$ in a pasteurizer (type A3-HRB; AlfaLaval). Both pasteurized creams (fortified and control) were kept at $4^{\circ} \mathrm{C}$ until use. Samples of the creams with and without vitamin $\mathrm{D}$ were taken before and after homogenization, after pasteurization, and after 3 days of storage at $4^{\circ} \mathrm{C}$ to determine vitamin $\mathrm{D}$ concentrations. The cream samples (approximately $10 \mathrm{~g}$ ) were stored at $-20^{\circ} \mathrm{C}$ in amber glass tubes until analysis.

The curd was prepared as described by Blanchette et al. (1996). For each batch, $100 \mathrm{~kg}$ of skim milk was standardized to $10 \%$ total solids with low-heat skim milk powder (Crino; Agropur, Granby, QC, Canada). After the milk was pasteurized $\left(74^{\circ} \mathrm{C}, 18 \mathrm{~s}\right)$ and then cooled to $33^{\circ} \mathrm{C}, 0.25 \mathrm{~mL} / \mathrm{L}$ of a $45 \%$ (wt/vol) calcium chloride solution (Calsol, Chr. Hansen, Hørsholm, Denmark; Fromagex, Rimouski, QC, Canada) was added. Thereafter, the milk was inoculated with $5.0 \%$ (wt/wt) of F-DVS Fresco 1000-21 mesophilic and thermophilic starter (Chr. Hansen). After $1 \mathrm{~h}$ at $33^{\circ} \mathrm{C}, 0.8 \%$ (vol/vol) rennet (Chy-Max Extra; Chr. Hansen; Fromagex) was added. After $5 \mathrm{~h}$ of acidification $(\mathrm{pH} 4.70)$, the curd was cut into cubes measuring approximately $1.5 \mathrm{~cm}^{3}$. The curd was then slowly heated for $90 \mathrm{~min}$ until it reached $55^{\circ} \mathrm{C}$. After removal of the whey, 2 washings were performed with water $\left(10^{\circ} \mathrm{C}\right.$ for the first washing and $4^{\circ} \mathrm{C}$ for the second) to lower the curd temperature to $7^{\circ} \mathrm{C}$. After draining and weighing, the curd was divided into 2 portions, each weighing $10 \mathrm{~kg}$. Both creams (fortified and control) were salted by adding 1.5\% (wt/ wt) $\mathrm{NaCl}$ (Hy-Grade, food grade; Sifto, Montreal, QC Canada). The salted cream was mixed with the curd at a ratio of $40: 60$, respectively $(4.4 \mathrm{~kg}$ of cream: $10 \mathrm{~kg}$ of curd), to obtain a final salt concentration of $0.6 \%$ (wt/ wt). The resulting cottage cheese was packaged in 500-g sealed polyethylene containers (IPL Inc., St-Damien, QC, Canada) and stored at $4^{\circ} \mathrm{C}$ for $21 \mathrm{~d}$.

After $1,7,14$, and $21 \mathrm{~d}$ of storage, samples of cottage cheese (with and without vitamin D) were taken randomly and homogenized in a Stomacher (model 400; Seward Medical, London, UK) for 4 min. The homoge- nized cheese samples (approximately $10 \mathrm{~g}$ ) were put into amber glass tubes and stored at $-20^{\circ} \mathrm{C}$ until analysis. To evaluate the possible diffusion of vitamin $\mathrm{D}$ through the cheese curds, $250 \mathrm{~g}$ of cottage cheese was placed in a stainless steel sieve (laboratory test sieve, mesh No. 7, aperture 2-80 mm; Retsch, Haan, Germany) and washed with $500 \mathrm{~mL}$ of cheese whey (Fromagerie Corneville; Agropur, St-Hyacinthe, QC, Canada) that had been rehydrated beforehand to $10 \%$ (wt/vol). The washed curd (approximately $10 \mathrm{~g}$ ) was stored in amber glass tubes and kept at $-20^{\circ} \mathrm{C}$ until analysis.

Milk composition was analyzed with a MilkoScan infrared analyzer (model FT-120; Foss North America, Eden Prairie, MN). The $\mathrm{pH}$ values during cheese manufacture and cheese storage were measured with a TitraLab $80 \mathrm{pH}$ meter (Radiometer; Rose Scientific, Edmonton, AB, Canada) equipped with a combined sealed glass electrode. Total lipids and total nitrogen were analyzed according to the Rose-Gottlieb and macro-Kjeldahl methods, respectively (AOAC International, 1995). Dry matter was determined after drying under vacuum in an oven $\left(100^{\circ} \mathrm{C}\right.$ for $5 \mathrm{~h}$; AOAC International, 2002). Cheese moisture was determined by difference $(100-\mathrm{DM})$. Sodium chloride concentration was analyzed with a chloride analyzer (model 926; Nelson-Jameson Inc., Marchfield, WI; AOAC International, 1995), and ash content was determined by incineration of $2 \mathrm{~g}$ of cheese for $16 \mathrm{~h}$ at $550^{\circ} \mathrm{C}$ (AOAC International, 1995). Minerals were extracted as described by St-Gelais et al. (1995) and determined with an inductively coupled plasma optical emissions spectrometer (ICP-OES; Prism High Dispersion ICP Spectrometer; Teledyne Leeman Labs, Burlington, ON, Canada).

Microbial populations in the cheeses were determined as described by St-Gelais et al. (1992). Mesophilic and thermophilic lactic acid bacteria were counted on M17 agar plates after $48 \mathrm{~h}$ of anaerobic incubation at $30^{\circ} \mathrm{C}$ (mesophilic bacteria) or $42^{\circ} \mathrm{C}$ (thermophilic bacteria).

The extraction of vitamin $\mathrm{D}$ was performed in a dark room as described by Boivin-Piché et al. (2016). Vitamin D was analyzed according to the method described by Boivin-Piché et al. (2016). In the present study, the sum of vitamin $\mathrm{D}_{2}$ and vitamin $\mathrm{D}_{3}$ is presented. Each analysis was carried out in triplicate.

Sensory evaluation was carried out to determine whether vitamin D could be added without a perceptible change in flavor. A triangle test for similarity was conducted. The untrained panel consisted of 60 judges who each tasted 3 samples (2 unfortified or fortified samples and 1 fortified or unfortified sample) and selected the odd sample. The samples were presented in random order. The experimental design balanced out the effect of order of presentation and the first-order 
carryover effect (MacFie et al., 1989). In terms of the critical values of the triangle test for similarity [maximum number correct as a function of the number of observations $(\mathrm{N})$, maximum $\beta$ of $5 \%$, and maximum allowable proportion of discriminators of $30 \%$ ], at least 25 respondents had to correctly pick the odd sample to reject the null hypothesis. The analysis was repeated twice.

An ANOVA was performed according to a factorial design to determine the effect of vitamin $\mathrm{D}$ on cheese composition and the effect of the different treatments (homogenization, pasteurization, and storage) on vitamin D concentration. A split-plot design was applied to determine the effect of storage time on vitamin $\mathrm{D}$ concentration. The presence of vitamin D and replicates were the main plots, and storage time was the subplot. The experiment was repeated 4 times, and significant differences were tested at $P<0.05$ according to the SAS/STAT procedure (version 9.3; SAS Institute Inc., Cary, NC).

The addition of vitamin D had no significant effect $(P>0.05)$ on cottage cheese composition (Table 1$)$. The same result was observed in Cheddar cheese fortified with vitamin D (Banville et al., 2000; Wagner et al., 2008; Ganesan et al., 2011). The mesophilic and thermophilic populations in control and fortified cottage cheese were not significantly different $(P>0.05)$ and did not change during $21 \mathrm{~d}$ of storage at $4^{\circ} \mathrm{C}$ (Figures $1 \mathrm{~A}$ and $1 \mathrm{~B}$, respectively). Few studies reported changes in starter populations in cottage cheese. Even though the moisture content of fresh cheeses is relatively high, the low $\mathrm{pH}$ and storage temperature do not allow for significant cell growth (Hough et al., 1999). Moreover, the nonsignificant cell count differences $(P>$ 0.05 ) between the fortified and unfortified cheeses after manufacture and after 15 days of storage showed that the presence of vitamin $\mathrm{D}$ did not affect the acidifying activity and survival of the starter. This result was similar to those obtained by Boivin-Piché et al. (2016), who observed no difference in the acidifying activity of milk fortified with vitamin $\mathrm{D}(5,000 \mathrm{IU} / \mathrm{mL})$.

After cheese production, the $\mathrm{pH}$ (5.05) was similar $(P>0.05)$ in the control and fortified cottage cheese (Figure 2) and similar to the $\mathrm{pH}$ of commercial cottage cheese (Brocklehurst and Lund, 1985). During cheese storage, the $\mathrm{pH}$ remained stable in both types of cheese, as reported by Schmidt and Bouma (1992) for $16 \mathrm{~d}$ of storage at $4^{\circ} \mathrm{C}$. The $\mathrm{pH}$ stability confirmed the low starter activity during cheese storage and the absence of an effect of vitamin D.

The sensory evaluation showed no significant difference between the fortified cream $(140 \mathrm{IU} / \mathrm{g})$ and the control cream, because only 21 of the 60 respondents correctly picked the odd sample. Ganesan et al. (2011)
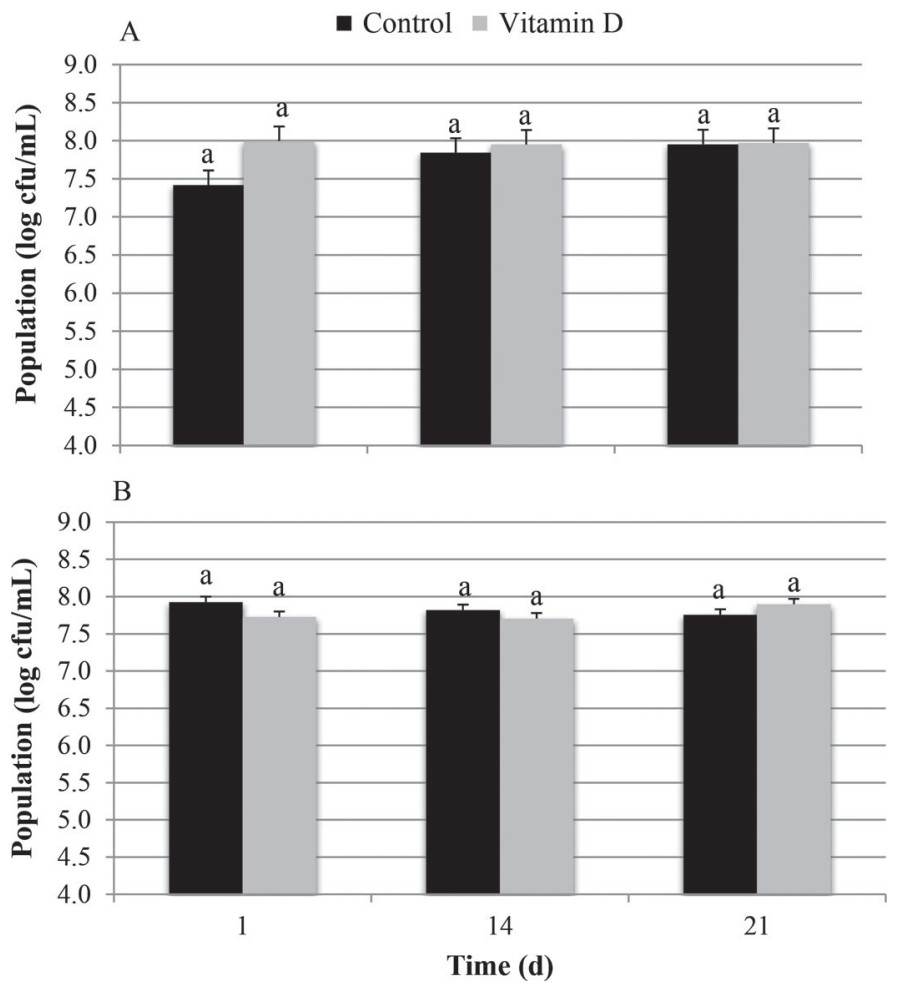

Figure 1. (A) Mesophilic and (B) thermophilic cell counts in control and vitamin D-fortified cottage cheeses during $21 \mathrm{~d}$ of storage at $4^{\circ} \mathrm{C}$. Error bars represent SEM. Means with the same letter were not significantly different $(P>0.05)$.

also concluded that vitamin D had no effect on the sensory properties of Cheddar cheese.

The effect of homogenization, pasteurization, and 3 days of storage on vitamin $\mathrm{D}$ stability in cream is

Table 1. Composition of control and vitamin D-fortified cottage cheeses after $14 \mathrm{~d}$ of storage at $4^{\circ} \mathrm{C}$

\begin{tabular}{lrrr}
\hline & \multicolumn{2}{c}{ Type of cheese } & \\
\cline { 2 - 2 } Item & Control & Vitamin D & SEM \\
\hline Constituent (\%) & & & \\
Moisture & $83.0^{\mathrm{a}}$ & $82.9^{\mathrm{a}}$ & 0.01 \\
Fat & $3.8^{\mathrm{a}}$ & $4.0^{\mathrm{a}}$ & 0.03 \\
Nonfat in DM & $13.2^{\mathrm{a}}$ & $13.1^{\mathrm{a}}$ & 0.03 \\
Total proteins & $9.5^{\mathrm{a}}$ & $9.6^{\mathrm{a}}$ & 0.33 \\
Salt & $0.6^{\mathrm{a}}$ & $0.6^{\mathrm{a}}$ & 0.01 \\
Ash & $0.8^{\mathrm{a}}$ & $0.8^{\mathrm{a}}$ & 0.01 \\
Mineral (mg/100 g) & & & \\
Calcium & $68.8^{\mathrm{a}}$ & $69.0^{\mathrm{a}}$ & 0.52 \\
Potassium & $66.7^{\mathrm{a}}$ & $69.2^{\mathrm{a}}$ & 4.36 \\
Magnesium & $6.3^{\mathrm{a}}$ & $6.4^{\mathrm{a}}$ & 0.08 \\
Phosphorus & $117.3^{\mathrm{a}}$ & $119.1^{\mathrm{a}}$ & 0.77 \\
Sodium & $421.5^{\mathrm{a}}$ & $418.4^{\mathrm{a}}$ & 4.63 \\
Zinc & $0.7^{\mathrm{a}}$ & $0.7^{\mathrm{a}}$ & 0.08 \\
Iron & $0.1^{\mathrm{a}}$ & $0.1^{\mathrm{a}}$ & 0.01 \\
\hline
\end{tabular}

${ }^{a}$ Means within a row with the same superscript letter were not significantly different $(P>0.05)$. 


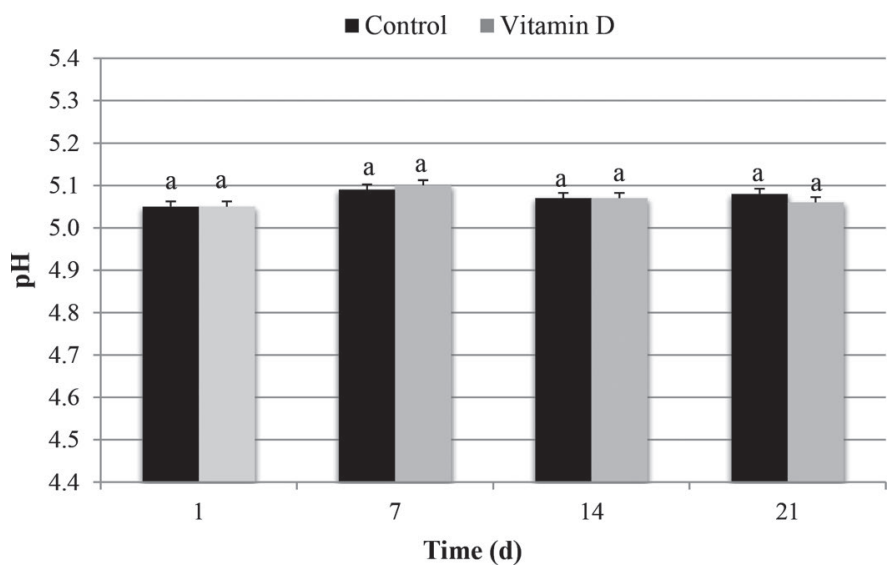

Figure 2. Changes in $\mathrm{pH}$ in control and vitamin D-fortified cottage cheeses during $21 \mathrm{~d}$ of storage at $4^{\circ} \mathrm{C}$. Error bars represent SEM. Means with the same letter were not significantly different $(P>0.05)$.

presented in Figure 3. The vitamin concentration was not significantly different $(P>0.05)$ in all creams and was approximately $140 \mathrm{IU} / \mathrm{g}$. Therefore, vitamin $\mathrm{D}$ in cream was not sensitive to the mechanical and thermal treatments or to storage for $3 \mathrm{~d}$. Similar results have been reported by Kazmi et al. (2007) and Wagner et al. (2008) for milk fortified with vitamin D before and after homogenization and pasteurization.

Figure 4 shows the vitamin $\mathrm{D}$ concentration in cottage cheese during $21 \mathrm{~d}$ of storage at $4^{\circ} \mathrm{C}$. The vitamin D concentration increased significantly from 51.4 to $55.2 \mathrm{IU} / \mathrm{g}$ between $\mathrm{d} 1$ and 7 and stayed relatively constant thereafter. This difference between $\mathrm{d} 1$ and 7 may be inherent to the technique used to extract vitamin $\mathrm{D}$ from the cottage cheese samples. However, the main result was the vitamin D stability in fortified cottage cheese over 3 wk of storage, indicating that vitamin D was not affected by the cottage cheese environment and not metabolized by the cottage cheese microflora. Wagner et al. (2008) demonstrated the stability of vitamin D in Cheddar cheese after 1 yr. In addition, because no vitamin $\mathrm{D}$ was detected in the cheese curds after $21 \mathrm{~d}$ of storage (data not shown), the vitamin D did not diffuse from the fortified cream toward the curds during the storage period.

The addition of vitamin $\mathrm{D}$ to the cream at the end of the manufacturing process allowed cottage cheese to be fortified without vitamin D loss or contamination of the cheese whey. Vitamin D is considered a contaminant in whey, and the resulting contaminated whey is difficult to manage. Therefore, the possibility of fortifying cottage cheese with vitamin D after the draining step by mixing fortified cream with the fresh cheese curds is a technological advantage specific to cottage cheese manufacture. Other important criteria are the

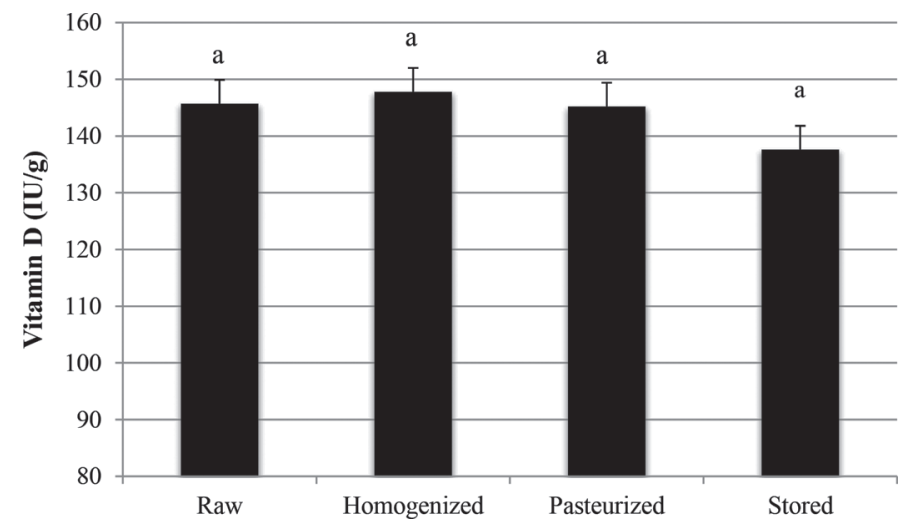

Figure 3. Vitamin D concentration in fortified raw cream and fortified cream after different treatments. Error bars represent SEM. Means with the same letter were not significantly different $(P>0.05)$.

resistance of vitamin $\mathrm{D}$ to different cream treatments and the stability of vitamin D after $3 \mathrm{wk}$ of storage at $4^{\circ} \mathrm{C}$. Our results confirmed the absence of an effect of vitamin $\mathrm{D}$ on the physicochemical, microbiological, and sensory characteristics of the fortified cheeses. In this study, the vitamin D concentration in the cream $(145.7 \mathrm{IU} / \mathrm{g})$ resulted in a cottage cheese that contained $51.4 \mathrm{IU} / \mathrm{g}$ without an effect on the characteristics and sensory properties of the cheese. This concentration could be easily modified according to the target level of fortification for the final product (for example, at a level similar to milk fortification). The resulting fortified cottage cheese could be considered a new source of vitamin $\mathrm{D}$ fortification or an alternative to vitamin $\mathrm{D}$ in drinking milk and could help reduce the proportion of the population that is deficient in vitamin $\mathrm{D}$.

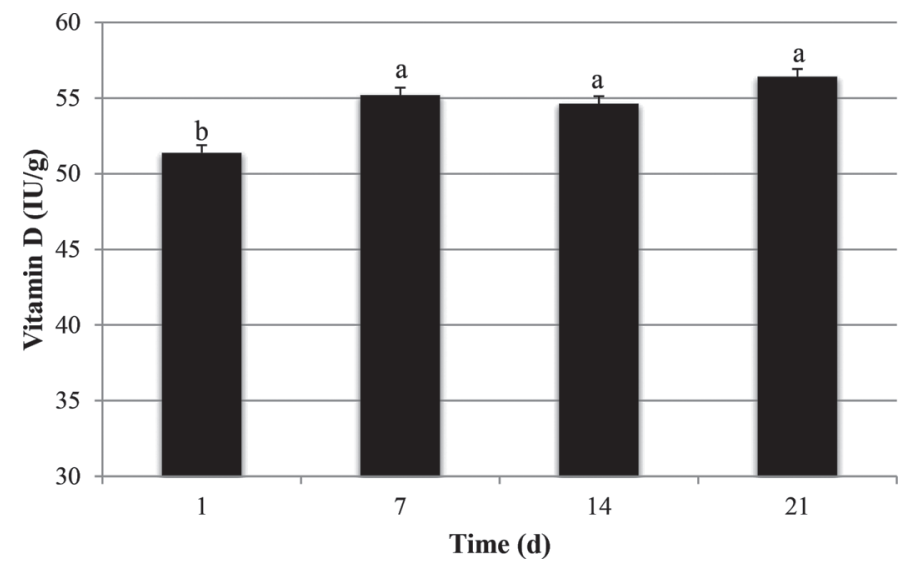

Figure 4. Vitamin D concentration in cottage cheese during $21 \mathrm{~d}$ of storage at $4^{\circ} \mathrm{C}$. Error bars represent SEM. Means with different letters (a, b) were significantly different $(P<0.05)$. 


\section{ACKNOWLEDGMENTS}

The authors thank Annie Caron and Sophie Turcot (St-Hyacinthe Research and Development Centre, Agriculture and Agri-Food Canada) for their technical assistance for the determination of microbial populations and cheese composition, and Jacinthe Fortin and Nancy Graveline (St-Hyacinthe Research and Development Centre, Agriculture and Agri-Food Canada) for sensory evaluation. This research was supported by a grant from Dairy Farmers of Canada (Ottawa, ON, Canada).

\section{REFERENCES}

AOAC International. 1995. Official Methods of Analysis. 16th ed. AOAC International, Gaithersburg, MD.

AOAC International. 2002. Official Methods of Analysis. 17th ed. AOAC International, Gaithersburg, MD.

Araújo, E. A., A. C. dos Santos Pires, M. S. Pinto, and A. F. de Carvalho. 2012. Cottage cheese: Fundamentals and technology. Pages 257-268 in Handbook of Animal-Based Fermented Food and Beverage Technology. 2nd ed. Y. H. Hui and E. Özgül Evranuz, ed. CRC Press, Boca Raton, FL.

Banville, C., J. C. Vuillemard, and C. Lacroix. 2000. Comparison of different methods for fortifying Cheddar cheese with vitamin D. Int. Dairy J. 10:375-382.

Blanchette, L., D. Roy, G. Bélanger, and S. F. Gauthier. 1996. Production of cottage cheese using dressing fermented by bifidobacteria. J. Dairy Sci. 79:8-15.

Boivin-Piché, J., J.-C. Vuillemard, and D. St-Gelais. 2016. Technical note: Vitamin D-fortified Cheddar type cheese produced from concentrated milk. J. Dairy Sci. 99:4140-4145.

Brocklehurst, T. F., and B. M. Lund. 1985. Microbiological changes in cottage cheese varieties during storage at $+7^{\circ} \mathrm{C}$. Food Microbiol. $2: 207-233$.

Ganesan, B., C. Brothersen, and D. J. McMahon. 2011. Fortification of Cheddar cheese with vitamin D does not alter cheese flavor perception. J. Dairy Sci. 94:3708-3714.

Holick, M. F., and T. C. Chen. 2008. Vitamin D deficiency: A worldwide problem with health consequences. Am. J. Clin. Nutr. 87:1080S-1086S.
Hough, G., M. L. Puglieso, R. Sanchez, and O. Mendes da Silva. 1999 Sensory and microbiological shelf-life of a commercial Ricotta cheese. J. Dairy Sci. 82:454-459.

Institute of Medicine. 2011. Dietary Reference Intakes for Calcium and Vitamin D. A. C. Ross, C. L. Taylor, A. L. Yaktine, and H. B. Del Valle, ed. National Academies Press, Washington, DC.

Kaushik, R., B. Sachdeva, and S. Arora. 2014. Vitamin $\mathrm{D}_{2}$ stability in milk during processing, packaging and storage. LWT Food Sci Technol. 56:421-426.

Kazmi, S. A., R. Vieth, and D. Rousseau. 2007. Vitamin $\mathrm{D}_{3}$ fortification and quantification in processed dairy products. Int. Dairy J. 17:753-759.

Langlois, K., L. Greene-Finestone, J. Little, N. Hidiroglou, and S. Whiting. 2010. Vitamin D status of Canadians as measured in the 2007 to 2009 Canadian Health Measures Survey. Health Rep. 21:47-55.

Lips, P. 2010. Worldwide status of vitamin D nutrition. J. Steroid Biochem. Mol. Biol. 121:297-300.

MacFie, H. J., N. Bratchell, K. Greenhoff, and L. V. Vallis. 1989. Designs to balance the effect of order of presentation and first-order carry-over effects in hall tests. J. Sens. Stud. 4:129-148.

Schmidt, K., and J. Bouma. 1992. Estimating shelf-life of cottage cheese using hazard analysis. J. Dairy Sci. 75:2922-2927.

St-Gelais, D., M. Piette, and G. Bélanger. 1995. Production of Cheddar cheese using milk enriched with microfiltered milk retentate. A preliminary study. Milchwissenschaft 50:614-619.

St-Gelais, D., D. Roy, and S. Haché. 1992. Growth and activities of Lactococcus lactis in milk enriched with low mineral retentate powders. J. Dairy Sci. 75:2344-2352.

Tippetts, M., S. Martini, C. Brothersen, and D. J. McMahon. 2012 Fortification of cheese with vitamin $\mathrm{D}_{3}$ using dairy protein emulsions as delivery systems. J. Dairy Sci. 95:4768-4774.

Wagner, D., D. Rousseau, G. Sidhom, M. Pouliot, P. Audet, and R. Vieth. 2008. Vitamin $\mathrm{D}_{3}$ fortification, quantification, and longterm stability in Cheddar and low-fat cheeses. J. Agric. Food Chem. 56:7964-7969.

Whiting, S. J., K. A. Langlois, H. Vatanparast, and L. S. GreeneFinestone. 2011. The vitamin D status of Canadians relative to the 2011 Dietary Reference Intakes: An examination in children and adults with and without supplement use. Am. J. Clin. Nutr. $94: 128-135$ 